\title{
Financial Control of Public Procurement to Prevent Corruption in the Development of Digital Economy
}

\author{
Isroilov B.I. ${ }^{1}$ Abduganiyev U. Kh. ${ }^{2 *}$ Ibragimov B.B. ${ }^{3}$ \\ ${ }^{1}$ Doctor of Economics, Professor, Head of the Department of the Lawyers`Training Centre under the Ministry of \\ Justice of the Republic of Uzbekistan,100052. \\ 2 intern researcher at the Lawyers`Training Centre under the Ministry of Justice of the Republic of Uzbekistan,100052. \\ 3 researcher \\ *Corresponding author. Email: uchqunbek90994@mail.ru
}

\begin{abstract}
The article considers the various authors' views on the issue of monitoring the effectiveness and legality of public procurement, provides a comparative description of the methods of financial control, as a result of a general analysis, the authors give their own opinions on the implementation of control in order to prevent and prevent corruption in public procurement. Besides, the article considers how public procurement can contribute to sustainable development, what kind of international experience in budget allocation of public procurement for this purpose, which legal regulations for implementing anti-corruption measures are required, what factors faster and impede the implementation of sustainable public procurement in the development of digital economy in Uzbekistan.
\end{abstract}

Keywords: financial control, public procurement, public procurement audit, digital audit, digital economy, prevention of corruption in public procurement

\section{INTRODUCTION}

As indicated by its economic essence the category "a state order" reflects social needs expressed through the state demand being also a way of satisfying the state demands. So, the place and the role of "a state order" of the economic activity of the state is a discussion topic among domestic and world scientists and specialists. The concept of "a state order" was prevailed as a component of a planned and distributive economy in Soviet practice.

A state order having been one of the planned acts of the distribution of products (goods) was targeted directly the enterprises and companies (direct contractors). However, Soviet scientists had different interpretations this definition as well, and the point of their views was that a state order is an offer to conclusion of goods supply contracts, i.e. an offer [1].

Currently, the notion of a state order is given various definitions and every researcher considers it differently. In one case it is an order made by the government departments or local government bodies and paid from budgetary funds for manufacturing of products, producing goods, performing some work in which the relevant public law education has an interest in it. The order processing can be made not only governmental and municipal enterprises but also by private ones. In this regard the governmental (municipal) order is a way of direct regulation of economic ties [2].

In the theory of Russian law, according to V.V. Melnikov, a state order is considered to be an order made by government bodies and paid from the state budget and extra-budgetary funds for the manufacture of products, producing goods, and some work in which the state is interested. In the narrow sense, a state order refers to a specific list of goods, activities, and services that are purchased by a specific government authority [3].

V.I. Kuznetsov suggests another definition for " a state order" as "a public law institution for the implementation of the Constitution, laws and functions of the Russian state in the form of an administrative regime of relations between the state and private law entities that contains substantive and procedural norms of constitutional, administrative, budgetary and civil law that implements legal status and the process of implementing the public law institute of public need established by the Constitution of the Russian Federation "[4].

The Law of the Republic of Uzbekistan "On Public Procurement" gives the following definition to the public procurement: "public procurement - the acquisition by the state customers of goods (works, services) for a fee" [5]. So, a state order should be considered as a justified and legally formalized need for goods, work and services for the state needs. And the placement of a state order means the actions of the state and authorized bodies to determine suppliers (contractors, executors) to conclude state contracts with them for the supply of goods, work or services.

An analysis of the world practice of the public procurement system shows that this economic mechanism is a powerful factor affecting the level of economic development. In developed countries, state orders are 
therefore widely used as one of the main ways for regulating the market and elements of a system to support economic and social stability, as well as a way to ensure the growth of the state economy as a whole. Economists believe that, the countries of the European Union (EU) have knowingly created a single European market for state orders. This mechanism allows manufacturers to navigate within the framework of the union in making certain decisions related of investments and structural transformations for state orders. Such a market approach to the regulation of public procurement simultaneously ensures the competitiveness of the economy as a whole. The total volume of public procurement of the countries of the Organization for Economic Development and Cooperation (OECD) is $11-12 \%$ of the total gross domestic product (GDP) (Fig. No. 1), while in the EU member states this figure is $15-20 \%$ of the total Union GDP. In high-tech industries, the share of public procurement can reach up to $50 \%$ of production (up to 2 trillion euros) [6].

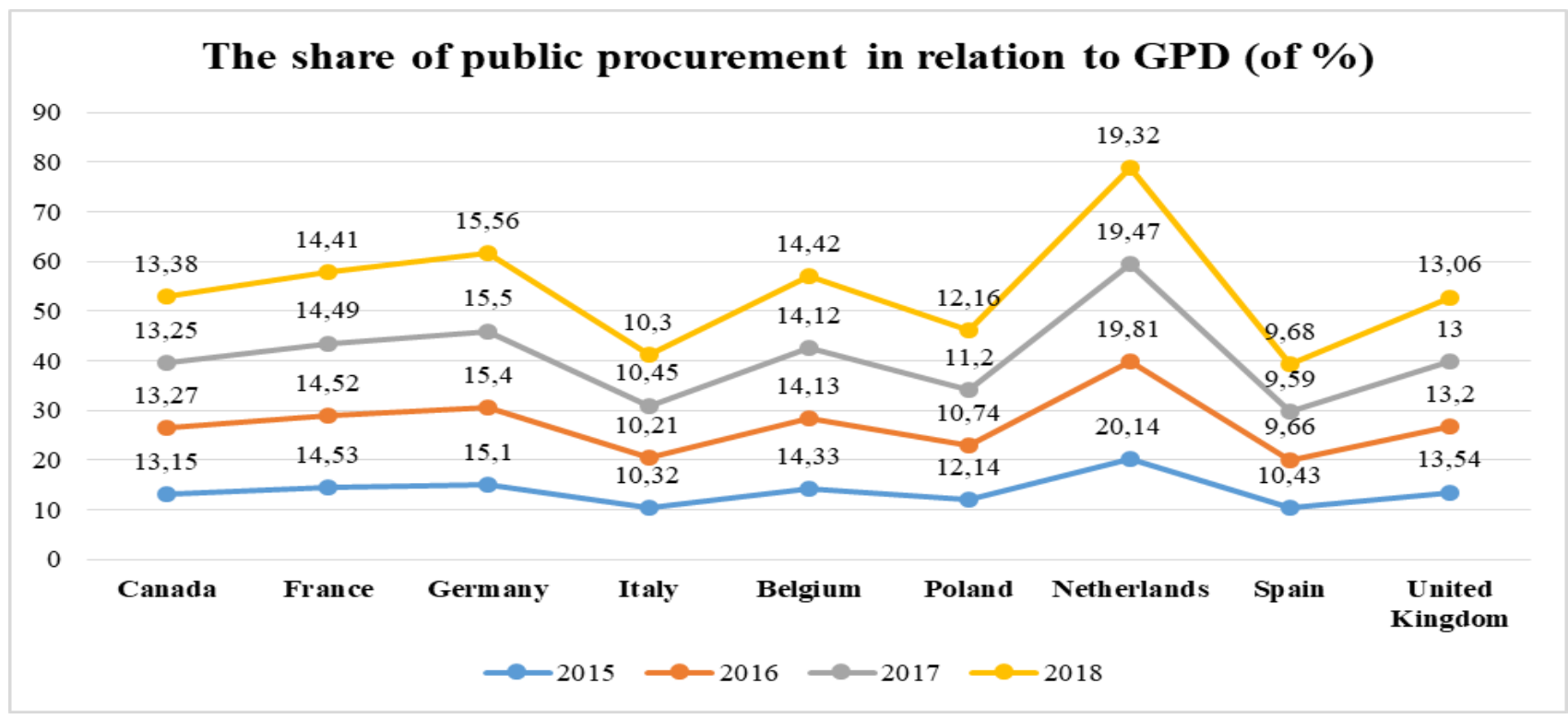

Figure 1 The share of public procurement in relation to GDP (of \%).

An analysis of the dynamics of expenditures for state needs in OECD countries also shows that over the years expenditures for state needs are growing. A larger share of the expenditures of the analyzed countries of the end of 2018 remains in the Netherlands (19.32), Germany (15.56), Belgium (14.42), and in other countries the share of expenditures exceeds the $13.0 \%$ barrier.

In the post-Soviet countries, at the initial stages of the transition to a market economy, the principles and mechanisms of placing the state order were not fully addressed. There were no clear regulations and a system of procurement legislation at all levels of government. Outside the reform framework, the most important stages of the overall process of ensuring state needs have remained:

- the procedure for planning and determining state needs;

- the formation mechanisms of orders for products for state needs;

- the procedure for financing and stimulating the implementation of state orders;

- monitoring the implementation of contracts and the responsibility of the parties.

As a result, this served to preserve the institutional prerequisites for corruption, abuse of official duties by officials for personal wealth while spending budget funds. Therefore, at present, an informal "shadow" institution of corruption has been formed in the field of public procurement, which impedes the development of a civilized market for government orders and the formation of an economic environment for establishing effective contractual relations between the state-customer and its suppliers.

The purpose of this study is to develop an audit mechanism to prevent corruption in public procurement. The main concept of the study is aimed at the formation of an audit in the field of public procurement. Effective work to prevent corruption is ensured through the formation of an internal control system. The risk factors in the field of public procurement should be taken into consideration and it can contribute to the prevention of corruption.

Materials and methods. The article analyzes the state of public procurement, their share in GDP and considers the organization of control in the field of public procurement, which can solve the problems of financial control in general for the implementation of anti-corruption policies. The method of making an audit of business transactions to comply with the legality of public procurement, in fact, is a set of methods, techniques, actions that allow the auditor: - assess the effectiveness of the external financial control system based on a risk-based approach;

- assess the effectiveness of the existing anti-corruption system and develop proposals for its improvement; 
- determine the degree of influence of internal and external threats on corruption risks.

First of all, the auditor has to determine the methods for analyzing and combating corruption when checking public procurement compliance with the law. An analysis of Uzbekistan's rating on the corruption perception index of the international non-governmental organization Transparency International in 2019 [7] allows us to conclude that in all historical periods of its development, within any state structure and type of government, corruption has been a national disease.

In 2019, corruption risk continues to cause serious concern among the leaders of international companies. More and more stringent anti-corruption measures are being taken in China, India, the United States, and Singapore. Only in 2019 in Uzbekistan, with financial control of institutions of the Ministry of Preschool Education (MPE), financial violations worth 11 billion soums were identified, of which theft and illegal expenses amount to $47.6 \%$, violations in the field of public procurement was $27.6 \%$ of the total amount of financial violations.

The head of the internal audit service of the MPE considered that "Public procurement of goods (work, services) should be carried out according to the procedure established by law. Non-compliance with this usually signals financial violations. The procedures are set so that each supplier can offer an honest price and receive an order. When suppliers are selected not only by the leader, the likelihood of corruption is reduced. [8]

In this regard, the state bodies of Uzbekistan are developing anti-corruption measures programs that include anti-corruption policies, financial control, the use of internal audit procedures and other financial monitoring mechanisms. In 2018, in Uzbekistan, construction and higher education were declared the "Year without corruption" [8]. In the bodies of the Ministry of Justice of the Republic of Uzbekistan, 2020 was declared the Year Without Corruption and the anti-corruption policy was approved. In his appeal to the new parliament the President of the Republic of Uzbekistan set the task of organizing a special anti-corruption body [9].

An analysis of world experience shows that one of the preventive measures to stop corruption and assess the awareness about the fight against it is a timely audit of public procurement. It is also one of the ways to protect and determine the legality of operations in the field of public procurement, as well as to combat corruption. The authors pay special attention to the state and problems in the field of public procurement in general, as well as their consequences.

The choice of methods and types of analytical procedures depends on the aim of their implementation, the availability and adequacy of the information necessary for conducting an audit of public procurement. During the audit, the evaluation of the planning methodology, comparing actual indicators with independently determined indicators and defining your assumptions based on prevailing trends, as well as calculating various factors and percentages based on reporting, normative indicators are vital.
The choice of coefficients, methods of their calculation and periods of time of calculation is made in accordance with regulatory documents and international audit standards. For identifying areas of potential risk these should be done:

- analysis of relative indicators of the current period;

- analysis of changes in relative indicators;

- comparison of changes in several types of relative indicators.

In the process of comparing actual reporting indicators with data from previous periods, the audit organization, already at the planning stage of the audit, identifies areas of potential risks. Common methods for identifying areas of potential risk are:

- comparison of indicators, average prices and analysis of their sharp changes;

- analysis of changes in indicators, average prices in comparison with changes in other bidders who participated in the tender. In this case, the area of potential risk is identified when a change in one indicator by economic nature does not correspond to a change in another indicator.

The application of analytical procedures will allow the auditor to establish whether a causal relationship exists for corruption agreements between the customer and public service providers.

The main objective of the analytical procedures is to identify the legality of the transaction and the answer to the question: are there corruption actions in the process of the transaction?

If the auditor finds unusual deviations that are not supported by evidence obtained from other sources, they should carefully examine them to personally convince himself of the objectivity and reliability of the analytical procedures.

When analyzing the magnitude of unusual deviations, the auditor should use criteria values based on regulatory documents. Any auditor should use criteria based on regulatory documents based on the analysis of the value of unusual deviations. The results of the analytical procedures should be used to obtain audit evidence and in the preparation of the audit report.

Having analyzed public procurement audit methods, it can be concluded that, there is no digital control in the organization and implementation of public procurement.

Currently, the world economy is undergoing a process of digitalization of the economy, but the legality, transparency and expediency of public procurement are still monitored with old methods. Therefore, when auditing public procurement, it is necessary to introduce digital control mechanisms. For this, in our opinion, first of all, it is necessary to form the legal basis for digital control. 


\section{DISCUSSION}

Many researchers note, the state order as one of the fundamental institutions of state regulation. In a mixed economy, the state acts as the largest customer and consumer of products number of industries, turning state demand into a powerful mechanism to regulating the economy, affecting its dynamics and structure [10].

Public expenditure is growing every year and now their share is almost half of GDP in industrialized countries and about one quarter in developing countries (Fig. 2). course of a century it grew rapidly and by the end the 1990s, the total state expenditures, as a percentage of GDP, in most developed countries averaged $45 \%$ (from $64.2 \%$ in Sweden to $32.4 \%$ in the USA) [11].

In post-socialist countries, the problems of strengthening (or, conversely, weakening) role of state in economy caused and are causing heated debate. On the one hand, scientists and specialists point out to the need to reduce public expenditure, limit the economic role of the state, another position is that in a capitalist society the economy usually functions successfully if the state controls about

\section{General government expenditures as a percentage of GDP in 2018}
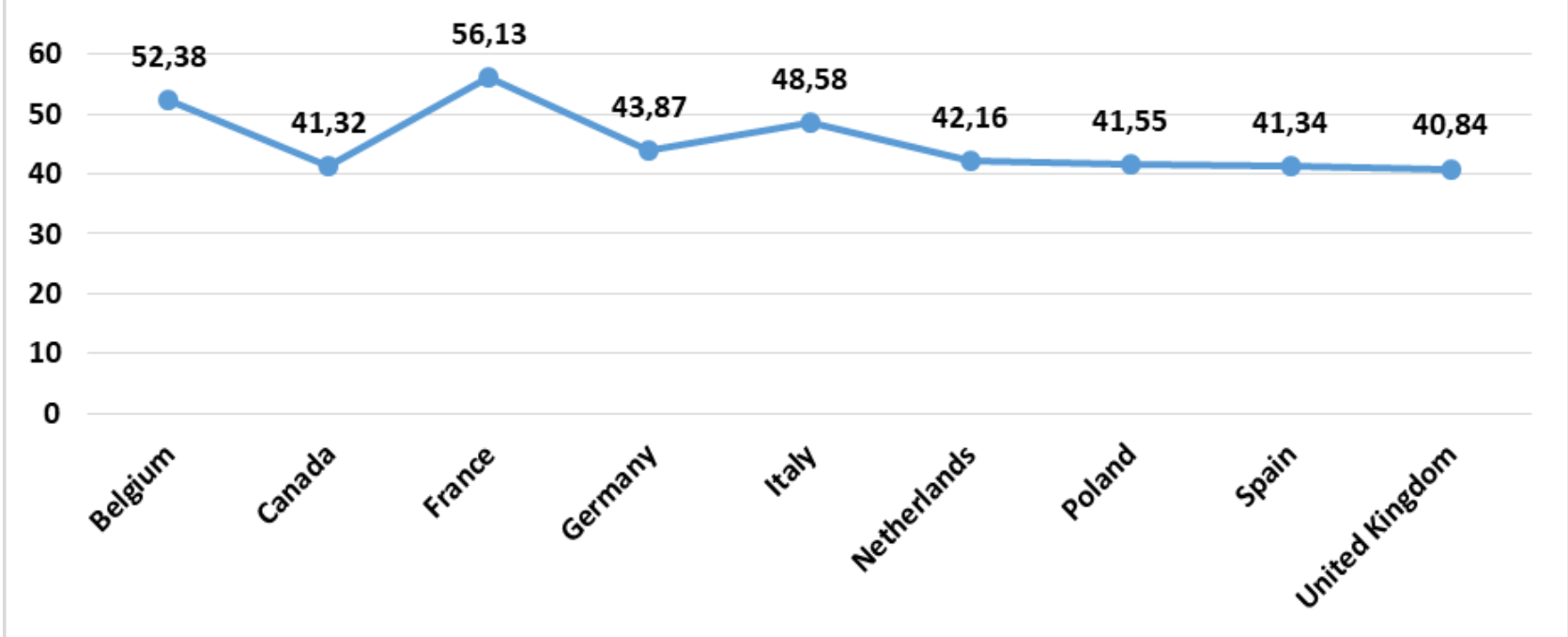

The indicator in the group of developed countries averaged

$50 \%$ of GDP [12].

$13.1 \%$ at the beginning of the 20th century, then over the

Figure 2 General government expenditures as a percentage of GDP in 2018

Analyzing share of public expenditure of consolidated budget in relation to GDP of the Republic of Belarus I.A. Kirsanova concludes that, in terms of the share of public expenditure in GDP, Belarus is inferior to the United States, approximately being equal to Western European countries in recent years [13].

As Yu.A. Perevyshina stated, "a change in the value of public expenditure has two impacts on the growth rate of output. Firstly, a raise in the share of public expenditure in GDP increases the marginal performance of private investments and encourages enterprises to intensively increase it, which ultimately accelerates economic growth. Secondly, need to finance an increased public expenditure leads to a raise in tax burden, which negatively affects accumulation of private capital and causes a decrease in economic growth. Usually, the first impact is stronger in economies with a small share of public expenditure in GDP, and the second dominates in countries where this share is high."

Analyzing the impact of public expenditure to economy, believes that if public expenditure in GDP up to $20 \%$ leads to an increase in economic growth, however, further increase in spending (above $20 \%$ of GDP) will lead to a slowdown in economic growth [14].

Japanese scientist Lee $\mathbf{J}$ (Lee $\mathbf{J}$ ) based on model of public expenditure and economic growth Barro (Barro), investigated the optimal size and structure of public expenditure. According to the results of this research, he concluded that with general restrictions on the parameters of budget expenditures, with a high income tax rate, economic growth will be low. With a relatively low income tax rate, if public expenditure is mainly directed to government investment, economic growth will be high [15].

Using endogenous growth module, Beenlon Chen studies of relationship between economic growth and public expenditure, public investment and consumption in one sector of economy. As a result of his research, the scientist discovered that the effect occurs when the marginal utility of private consumption, in comparison with the marginal utility of public consumption, is greater. As a result, this process stimulates public investment and accelerates economic growth [16]. 
In East Asian countries, this has already been practically proved, where share of public investment is optimal and economic growth is higher than in other countries of the region.

Sugato Gosh (By Sugata Chosh) and Andros Grigorio (and Andros Grigorio) using GMM methods using panel data for 15 developing countries over 28 years concluded that current and capital expenditures have a significant positive or negative impact on economic growth. For example, operating and maintenance costs have a stronger effect on growth than health and education costs [18].

Reportedly data OECD of Uzbekistan, the general statistics on procurement by strategic entities for 2017 indicates that the amount of procurement contracts amounted to about 38.2, and in 2018, 17.1 trillion. soums. The share of purchases through direct conclusion of contracts is $31 \%$, while the share of contracts concluded on the basis of though competitive, but transparency lacked selection of the best offers is $57 \%$ [19].

While having of general principles for selecting the best offers and requirements for their mandatory examination and registration, the authorized body does not have a clear detailed regulation defined by law and centralized control over their procurement activities.

An analysis of the effectiveness and appropriateness of public expenditure indicates need to strengthen control over the targeted and legitimate operation of using budget funds allocated for this area. To determine how efficiently and purposefully budget funds are used, an independent financial control is needed, which is an audit.

In our opinion, one of the mechanisms of independent financial control is digital audit. An analysis of domestic and foreign audit practices in the field of public procurement shows that at present there are no special software products for digital control. To improve and ensure the effectiveness of independent financial control, it is necessary to develop software products for digital audit on the basis of public procurement legislation, as well as national and international audit standards.

\section{RESULTS}

As noted by foreign, national scientists and specialists, measures aimed at combating corruption require a wide range of activities, as well as the integration of the work of specialists with the general public. In order to prevent and combat corruption, in our opinion, it is also necessary to closely link prevention and prevention methods, as integration and cooperation, transparency and accountability, reduction of risks and opportunities, and control among themselves.

An analysis of the conclusions of this research show that relevance of the topic is due to the fact that in domestic economic science and practice a number of problems of organizational and legislative support of procurement for state needs have not been resolved. As a result, there are many problems in the public procurement system that needs to be addressed immediately. One of the best solutions for determining the legality of organizing and conducting public procurement is to organize the correct financial control of operation to prevent corruption in public procurement.

The level and quality of financial control system is determined by degree of development of financial and industrial sectors, centralization of the management of the economies of countries, as well as the social sphere. One of the most effective methods of compliance with the current legislation on the organization and purchase of inventory items, services for needs of the state is audit. Therefore, in all developed countries of the world, special attention is paid to this method of financial control.

In our opinion, financial control, which is provided for internal audit, is a measure aimed at combating corruption. Therefore, it is necessary to introduce mechanisms to ensure disclosure of information on the financial performance of departments and on effectiveness of their control by determining the scope of internal control and internal audit, including the legal status and competence of internal control and internal audit services, as well as measures to combat corruption and the shadow economy, concerning the development of public administration, forecasting and strategic planning.

In article 13 of the Federal Law of the Russian Federation "On Auditing" this issue is provided. The law obliges auditors to inform founders of inspected person, their representatives about cases of corruption offenses that they became aware of, including cases of bribery of foreign officials, and in some cases inform law enforcement authorities about this [20].

International Auditing Standards (ISAs) [21] also oblige auditors to audit financial statements:

- consider compliance by the audited entity with legislative and other regulatory legal acts, including the requirements of anti-corruption documents;

- implement appropriate procedures for organizing public procurement, assess whether there are corruption risks.

One of the authors has previously considered mechanisms for determining fraud during the audit and presented with examples [22].

Despite positive nature of law on public procurement of ongoing reforms in the field of audit [23], as well as national audit standards of the Republic of Uzbekistan:

- there are still no norms regarding the implementation of risk assessment procedure and corruption risk assessment; - under the Law on Public Procurement, purchases made by strategic entities do not fall;

- there are no norms in the legislative acts regulating digital audit;

- digital control mechanisms are not applied in order to prevent corruption in the practice of public procurement audit;

- There is no special law regulating of activities state financial control system of the Republic of Uzbekistan.

\section{CONCLUSIONS}

Over the past four years, Uzbekistan has been implementing global reforms in all areas of economy. A 
legislative framework has been created to early warning, prevention and combat corruption. The Law on State Financial Control is being developed.

In the audit system over the past 29 years there have been and are significant changes that are legislative, professional and substantive. In connection with the phased transition to international financial reporting standards (IFRS), audit is becoming one of the tools to ensure independent financial control.

Studies of foreign scientists and specialists prove the fact that history of the audit and prospects for its development are of great interest to the world community. From January 1, 2021, the procedure for accounting and financial reporting on the basis of IFRS is established. The roadmap for implementing audit development program in Uzbekistan was approved [24].

Today, as part of the ongoing reforms, international experts are often hired to draft bills and government programs. The costs of hiring experts are allocated from the state budget and through grants and loans from international institutions. But there is no transparency on these services.

In our opinion, to hire foreign experts it is necessary to justify the involvement of international experts by declaring the tasks to be performed, the amount of funds allocated to foreign experts by state bodies. In these areas, it is also necessary to introduce mechanisms for financial monitoring of government spending. In order to ensure transparency, cost information should be publicly available.

The prospect of audit development is associated not with classical audit of financial statements, but with forecasts of the development of organizations, the definition of channels for the theft of public funds and the risks of the threat of corruption. Currently, audit issues in the system for ensuring effectiveness of individual public procurements are also among the most relevant. Therefore, correct organization and planning of providing conditions for the economic growth of all subjects of legal relations directly depends on their decision.

As one areas of audit activity, the audit of the system in public procurement allows us to give the most complete assessment and understanding of reasons for the effectiveness of use of budget funds, as well as audit procedures that will prevent large losses in the future by revising the development strategy of public procurement sphere. Audit procedures will determine the degree of minimization of threats, both external and internal.

One of the most important links in the system of ensuring legality and effectiveness of public procurement is its promptness and timeliness. In fact, the audit is universal, since it allows you to solve several control functions: financial, informational, political, legal, anti-corruption, management and personnel.

In this regard, it becomes possible to develop and implement a set of proactive measures aimed at reducing the level of threats in the financial sector, as well as increasing its stability, sustainability and effectiveness, which are main competitiveness.
Therefore, relying on the analysis of experience and mechanisms of financial control in order to ensure legality and effectiveness of public procurement, we consider that: -It is necessary to stipulate an internal and external audit as an alternative control mechanism for public procurement in order to identify and prevent violations of the law, as well as the prevention of corruption offenses while developing the Law "On State Financial Control";

- internal and external audit as an alternative control mechanism in public procurement in order to identify and prevent violations of the law, as well as the prevention of corruption offenses;

- standards permitting the use of digital audit in the field of financial control to detect violations;

- the procedure for independent certification of employees of state financial control;

- the procedure for the deprivation and suspension of the validity of the certificate in the event of detection of gross financial violations;

- the concept of conflict of interest must include affiliates of potential bidders;

- improve the mechanism for identifying and preventing conflicts of interest in public procurement, by disclosing information about ultimate beneficial owners of procurement participants;

- Government should be obligated to criminalize a participation in public procurement of companies in which affiliates or heads of state bodies are organizer or have a conflict of interest in public procurement.

\section{REFERENCES}

[1] Etymological dictionary of the Russian language. Moskow, 1975. p. 35;

[2] Ozhegov S.I., Shvedova N.Yu. Explanatory dictionary of the Russian language. Moskow, 1994. p.74.

[3] V.V. Melnikov. Improving the mechanism of public procurement based on increasing the efficiency of competitive bidding in the Russian Federation: Diss. Cand. econ. Sciences.-Novosibirsk, 2005.

[4] V.I. Kuznetsov. Legal regulation of the state order institution: dis. Cand. legal Sciences: 12.00.14. M., 2005. p. 86.

[5] The Law of the Republic of Uzbekistan "On Public Procurement". "Collection of Legislation of the Republic of Uzbekistan", April 16, 2018, N 15, p. 302.

[6] P.S. Yunusova. State order in the economic activity of the region. RPTE. 2010, No.3.

[7] Corruption Perception Index. https://www.transparency.org/cpi 2019. 
[20] Federal Law of the Russian Federation "On Auditing".

http://www.consultant.ru/document/cons_doc_LAW_8 $3311 /$.

[21] International Standards on Auditing (ISA). International Federation of Accountants https://www.ifac.org/

[22] B.I. Isroilov, A.Zh. Tuychiev. Audit Fraud Mechanisms. MNPK. "SPbPU Science Week", November 19-24-November 2018, p. 119.

[23] The Law of the Republic of Uzbekistan "On Auditing". "Vedomosti of the Oliy Majlis of the Republic of Uzbekistan", 2000, N 5-6, Article 149.

[24] Decree of the President of the Republic of Uzbekistan dated February 24, 2020 N PP-4611 "On additional measures for the transition to international financial reporting standards." / "Narodnoe slovo", February 26, 2020. National database of legislation (www.lex.uz), February 25, 2020. monetarism? // Society and economics. 2008. N 10 - 11. p. 145 .

[13] Smotritskaya I., Chernykh S. Public procurement in the system of relations between the state and the market // Society and Economics.-№ 1.-2010.-p. 78-87.

[14] I.A. Kirsanova. Public procurement as an institution of macroeconomic regulation. // elib.bsu.by >bitstream. 2010 year

[15] Yu.N. Perevyshin. The influence of the share of government spending in gross domestic product on economic growth rates. // Economic analysis: theory and practice, No. 4 (2016). from. 57-71.

[16] Lee J. Optimal Size and Composition of Government Spending. Journal of the Japanese and International Economies, 1992, vol. 6, no. 4, pp. 423439 .

[17] Chen B. Economic Growth with an Optimal Public Spending Composition. Oxford Economic Papers, 2006, no. 58, pp. 123-136.

[18] Ghosh S., Gregoriou A. The Composition of Government Spending and Growth: Is Current or Capital Spending Better? Oxford Economic Papers, 2008, no. 60, pp. 484-516. doi: 10.1093/oep/gpn005.

[19] [Electronic resource] Gazeta.uz website. https://www.gazeta.uz/ru/2019/05/28/state-

procurements/ 